Marquette University

e-Publications@Marquette

Finance Faculty Research and Publications

Business Administration, College of

$10-1-2007$

\title{
Interest Rates in the Sub-Prime Mortgage Market
}

Souphala Chomsisengphet

Anthony Pennington-Cross

Marquette University, anthony.pennington-cross@marquette.edu

Accepted version. "Interest Rates in the Subprime Mortgage Market," in Household Credit Usage: Personal Debt and Mortgages. Eds. Sumit Agarwal and Brent W. Ambrose. New York: PalgraveMacmillan Publishing, 2007: 237-252. Publisher Link.

Souphala Chomsisengphet and Anthony Pennington-Cross, "Interest Rates in the Subprime Mortgage Market," 2007, Palgrave-Macmillan Publishing reproduced with permission of Palgrave Macmillan. This extract is taken from the author's original manuscript and has not been edited. The definitive version of this piece may be found in Household Credit Usage by Brent W. Ambrose and Sumit Agarwal which can be purchased from www.palgrave.com.

This is only an excerpt of the published book chapter, approximately equivalent to $10 \%$ of the original document. For the full text, please see the publisher's website. 


\title{
Chapter 14
}

\section{Interest Rates in the Sub-Prime Mortgage Market}

\author{
By Souphala Chomsisengphet and Anthony Pennington-Cross
}

\section{Introduction}

Sub-prime lending has grown rapidly in the mortgage market. According to Inside Mortgage Finance (IMF), sub-prime mortgage lending increased from approximately 65 billion dollars in 1995 to over 213 billion dollars in 2002 . This growth accelerated in 2003 as the market grew by another 119 billion dollars to reach 332 billion dollars (IMF 2004). ${ }^{1}$ By providing access to credit to those otherwise denied a mortgage in the traditional prime market, the sub-prime market can enhance welfare by completing the mortgage market (Chinloy and MacDonald 2005). Sub-prime credit gives more households the opportunity to become homeowners, as well as providing better access to equity held in the home through refinances and second mortgages. Despite the growth in sub-prime lending, little is known about the pricing of the sub-prime credit. This chapter helps fill this gap by examining the determinants of interest rates charged to subprime mortgage borrowers.

The most unique characteristic of sub-prime mortgage lending is that it charges more than the prime mortgage market and the charges include a wide variety of prices (interest rates and fees). ${ }^{2}$ The growth of the sub-prime mortgage market suggests that risk-based pricing is a viable method of lending in the mortgage market. Sub-prime has introduced into the mortgage market risk-based pricing by sorting borrowers into a dozens of categories, each with its own interest rate. Hence, sub-prime mortgage lenders can move further away from the traditional accept-reject decision, which dominates prime lending, closer to identifying the correct riskbased price for each potential borrower. In this chapter, we find that interest rates in the subprime mortgage market are strongly impacted by a complicated interaction of downpayment and borrower credit history. This is in contrast with the prime market where interest rates are primarily driven by downpayment, given that minimum credit history requirements are satisfied.

\section{Background}

The growth and maturation of sub-prime has been accompanied by lender consolidation and a change in the type of institution originating loans. IMF reports that the market share of the top 25 originators in sub-prime ${ }^{3}$ grew from 39.3 percent in 1995 to 93.4 percent in 2003. This rapid consolidation has been a function of individual firm failures, as well as mergers and 
acquisitions by traditional lenders seeking to move into the potentially lucrative sub-prime market. Table 14.1 lists the top ten sub-prime originators reported by IMF for 1996 and 2003. Most of the firms listed in 1996 are not included in the 2003 list. ${ }^{4}$ In 1996 most of the originators were independent finance companies, but by 2003 Household Financial Services was the only finance company to remain independent and survive market consolidation and entry of traditional prime lenders.

In addition, the prevalence of sub-prime loans in the secondary market has changed as well. The securitization rate ${ }^{5}$ of sub-prime home mortgages has grown from 28.4 in 1995 to 58.7 percent in 2003. While the rate is still below the prime market rate (75.9 percent in 2003), it has helped bring the sub-prime market into a form more closely resembling the prime market (IMF 2004). In fact, the securitization rate exceeds the rate in the conventional market rate in 19951997. Perhaps due to information asymmetries between primary and secondary markets, subprime lenders are less likely to securitize mortgages if they come from locations with improving but poor economic conditions (Pennington-Cross 2002). Furthermore, Fannie Mae and Freddie Mac have started to impact the structure of sub-prime securities. Trade magazines even refer to GSE class securities, which contain AAA-rated tranches backed by loans below the conforming loan limit. ${ }^{6}$ In 2004, IMF reports that Fannie Mae and Freddie Mac purchased 43.7 percent of total sub-prime issuances, up from 39.8 percent in $2003 .^{7}$ 